\title{
FIRST RECORD OF BICEPHALY IN THE BRAZILIAN SHARPNOSE SHARK, Rhizoprionodon lalandii
}

\author{
Aline Cristina Prado ${ }^{1,2}$, Renata Daldin Leite ${ }^{1,2}$, Eduardo Koerbel ${ }^{3}$, Hugo Bornatowski², Érica Padilha ${ }^{4}$ \\ and Natascha Wosnick ${ }^{1,2^{*}}$ \\ ${ }^{1}$ Programa de Pós-Graduação em Zoologia, Universidade Federal do Paraná, Curitiba, Paraná, Brasil. Email: \\ n.wosnick@gmail.com \\ ${ }^{2}$ Associação MarBrasil, Pontal do Paraná, Paraná, Brasil. \\ ${ }^{3}$ Vida Livre Medicina de Animais Selvagens, Curitiba, Paraná, Brasil. \\ ${ }^{4}$ Pontifícia Universidade Católica do Paraná, Curitiba, Brasil.
}

\begin{abstract}
RESUMO
Deformidades congênitas são relativamente comuns em raias e tubarões. O presente estudo teve como objetivo descrever um caso de bicefalia em um embrião de $R$. lalandii. Através de imagens radiográficas e avaliação da condição externa e interna do embrião em comparação com um jovem do ano sem deformidades da mesma espécie, foi possível caracterizar a anormalidade observada. Tais dados são importantes para determinar a frequência e tipos de anomalias observadas em elasmobrânquios, permitindo assim o maior conhecimento sobre as anormalidades de desenvolvimento no grupo e suas possíveis causas.

Palavras-chave: malformação; tubarão; espécie endêmica; morfologia.

ABSTRACT

Congenital deformities are relatively common in rays and sharks. The present study aimed to describe a case of bicephaly in an $R$. lalandii embryo. Through radiographic images and evaluation of the external and internal condition of the embryo in comparison with a young of the year with no deformities of the same species, it was possible to characterize the abnormality observed. Such data are important to determine the frequency and types of anomalies observed in elasmobranchs, thus allowing greater knowledge about developmental abnormalities in the group and their possible causes. Keywords: malformation; shark; endemic species; morphology.
\end{abstract}

\section{INTRODUCTION}

The Brazilian sharpnose shark, Rhizoprionodon lalandii Müller \& Henle, 1839, is a small-sized shark (80 cm in Total Length), with distribution restricted to the Western Atlantic Ocean, from Panama to southern Brazil (Compagno, 1984; Bornatowski \& Abilhoa, 2012). It is a tropical coastal specie found on the continental shelf at depths up to $70 \mathrm{~m}$ (Compagno et al. 2005). The reproductive mode is placental viviparity with up to five embryos per breeding cycle (Motta et al. 2007). In southeast and southern Brazil, Rhizoprionodon lalandii is an important fishing resource, representing about $60 \%$ of shark landings considering both targeted and incidental artisanal captures (Gadig et al. 2002; Motta et al. 2005). In Paraná state, southern Brazil, the species is landed during winter and spring, being neonates and females at final gestation stages the most frequently caught (Costa \& Chaves, 2006). Such capture pattern is constant, being a strong evidence of the importance of the region as a parturition/nursery area for the species.

Morphological deformations or abnormalities have been reported at different levels in elasmobranchs. During embryonic development, certain morphological abnormalities might be fatal (e.g., bicephaly), with only one case of functional bicephalic elasmobranch reported in the literature (Rhinoptera steindachneri) (Castro-Aguirre \& Torres-Villegas, 1979). Bicephaly or dicephaly is characterized by parapagus twins (generally same sex) conjoined with two fully formed heads laterally attached to each other, being the posterior region fused at different degrees (Spencer, 2000; Bondeson, 2001). It is a deformity that occurs when there is duplication of the neural tube from a single fertilized egg (Carles et al. 1995; DeLahunta \& Glass, 2009). In sharks, cases of embryonic bicephaly have been reported for the genus Carcharhinus, Galeorhinus, 
Squalus, Prionace and Rhizoprionodon (MuñozOsorio et al. 2013; Wagner et al. 2013; Delpiani et al. 2011; Galván-Magaña et al. 2011; dos Santos \& Gadig, 2014). In Brazil, there are only two cases of bicephaly reported in the literature, an embryo of Pseudobatos percellens (Bornatowski \& Abilhoa, 2009) and an embryo of Rhizoprionodon porosus (dos Santos \& Gadig 2014).

On a global scale, there are only two reports of congenital anomalies for Rhizoprionodon spp. with deformations like the reported in the present study (Dos Santos \& Gadig, 2014). Although the causes and origin of morphological abnormalities in elasmobranchs are unknown and the target of speculation, reports are imperative in order to determine the frequency of congenital anomalies in the group. That said, the present study aimed to describe a case of bicephaly in Rhizoprionodon lalandii embryo in order to update the list of occurrences for elasmobranchs.

\section{MATERIALS AND METHODS}

\section{Specimen sampling and initial evaluation}

The fetus was removed from a pregnant female incidentally caught in a gillnet during an artisanal fishing campaign performed by fishermen from the municipality of Matinhos, Paraná state $\left(25^{\circ} 49^{\prime} 04\right.$ "S and $48^{\circ} 32$ ' $34^{\prime \prime} \mathrm{O}$ ) in June 2018. The embryo was sexed, measured, weighed and frozen for further laboratory analysis. As only this embryo was donated by fishermen, we had no access to maternal morphological measurements and physical condition.

The animal was taken to the Laboratório de Zoologia Geral at Universidade Federal do Paraná and subjected to identification according to Figueiredo (1977). Specific measurements of the abnormal embryo were taken and compared with a young of the year (YOY) with no deformities of the same species that was incidentally caught in a gillnet during another fishing campaign also performed by artisanal fishermen of Matinhos.

\section{Diagnostic imaging and necropsy}

After identification, the embryo was taken to the Hospital Veterinário do Batel in the municipality of Curitiba (Paraná state) for radiography (CR30-X model) in order to evaluate its general morphology and diagnose the anomalies. The cartilaginous nature of elasmobranch skeleton made radiographic analysis difficult to perform. Radiographic evaluation was performed in dorsal and ventral view and adjusting the embryo's position when necessary for better visualization of the animal's anatomy.

After radiography, necropsy was performed following Dos Santos \& Gadig, 2014. Descriptions of external morphological anomalies were made following Okazaki et al. (1987) and Kaufman (2004) and description of internal morphology was made according to Stoskopf (1993).

\section{Tumbling}

After the external and internal morphological evaluations, the specimen was tumbled in the Museu de História Natural do Capão da Imbuia under the identification MHNCI 12695.

\section{RESULTS}

\section{External morphology}

The embryo was identified as female with 9.4 $\mathrm{cm}$ of total length (TL) and 26g of weight. General measurements and comparison with a normal young of the year (YOY) are presented in Table 1.

In dorsal view, the embryo had a dark gray color with dermal denticles covering the whole body, similar to the normal YOY. Head bifurcation was prior to the pectoral fins (Figure 1A). In ventral view, both heads had a well-developed pair of eyes, a pair of nostrils, jaws with developed teeth, Lorenzini ampullae with similar distribution, five pairs of gill slits on each side of the body, and an extra shared gill slit located in the middle of the bifurcation (Figure $1 \mathrm{~B}-\mathrm{D}$, arrow). The right head (in dorsal view) was bigger, with $41 \mathrm{~mm}$ in TL while the right head measured $39 \mathrm{~mm}$ in TL. The teeth and the rostrum were also more developed in the right head and the left head was smaller and less defined (Figure 1 C-B).

The caudal fin had a spiral shape and was curved to the left; the anal and the second dorsal fin were absent. The other fins were present and normal when compared to the YOY (two pectoral, one dorsal and two pelvic) (Figure 2A). There was no abnormality in the cloacal opening. A little above to the pectoral fins, in the center of the body, an open umbilical scar with cord remnants was observed (Figure 2B).

\section{Internal morphology}

A comparative analysis of the internal anatomy of the abnormal embryo with the YOY showed welldeveloped normal organs in terms of shape, size, and position without duplication (Figure 3).

It was possible to observed that the single 
Table 1. Measurements of the deformed embryo (bicephalous) and the young of the year (YOY) Rhizoprionodon lalandii.

\begin{tabular}{l|c|c|c}
\hline \multirow{2}{*}{ Measurement $(\mathbf{m m})$} & \multirow{2}{*}{ YOY } & \multicolumn{2}{c}{ Bicephalous } \\
\cline { 3 - 4 } & & left & right \\
\hline Total length & 330 & 94 & 94 \\
\hline Fork length & 275 & 85 & 91 \\
\hline Pre caudal length & 245 & 79 & 83 \\
\hline Head length & 75 & 39 & 41 \\
\hline Preoral length & 35 & 18 & 19 \\
\hline Preorbital length & 30 & 18 & 19 \\
\hline Prenostril length & 20 & 11 & 12 \\
\hline Eye diameter & 10 & 5 & 5 \\
\hline Mouth width & 13 & 10 & 10 \\
\hline Mouth length & 20 & 10 & 7 \\
\hline Distance between first pair of gill slits & 3 & 1 & 2 \\
\hline Distance between first and fifth gill slits & 10 & 5 & 5 \\
\hline Snout to gill & 63 & 37 & 37 \\
\hline Snout to cloaca & 165 & 68 & 71 \\
\hline Cloaca to tail base & 100 & 13 & 13 \\
\hline Pelvic fin anterior margin & 160 & 65 & 60 \\
\hline Pelvic fin posterior margin & 180 & 68 & 65 \\
\hline Pre first dorsal length & & 37 & 49 \\
\hline Pre second dorsal length & absent & absent \\
\hline & & & \\
\hline
\end{tabular}

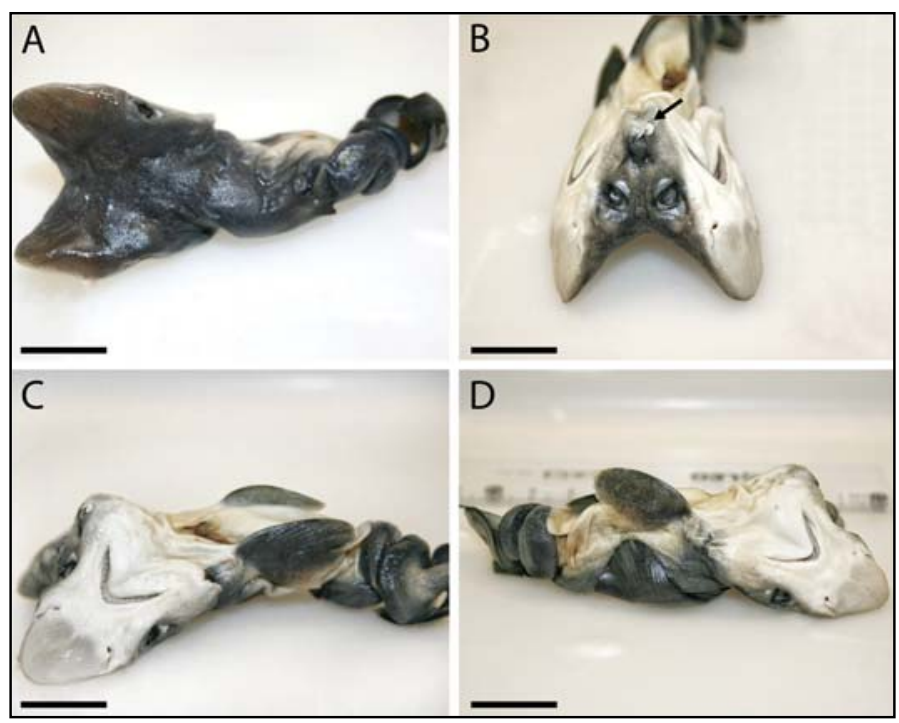

Figure 1. Embryo external morphology. A) dorsal view showing the head bifurcation; B) ventral view - pairs of eyes, mouths with developed teeth and shared gill slits (arrow); C) ventral view of the right head D) ventral view of the left head. Scale bar $1 \mathrm{~cm}$. 


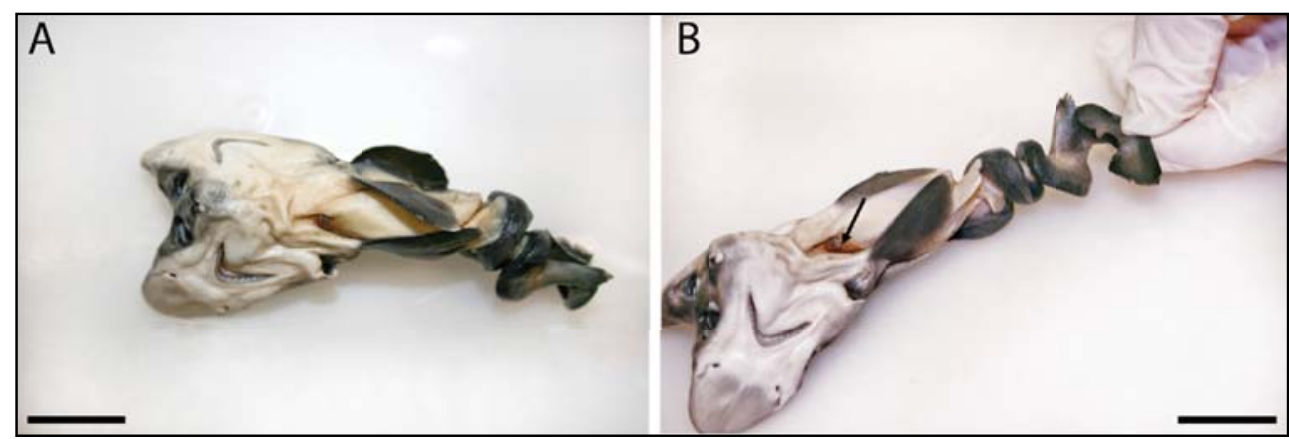

Figure 2. A) ventral view of the normal pectoral and caudal fins. B) Absent anal fin, caudal fin with a spiral shape and umbilical cord opening with cord remnants (arrow). Scale bar $1 \mathrm{~cm}$.

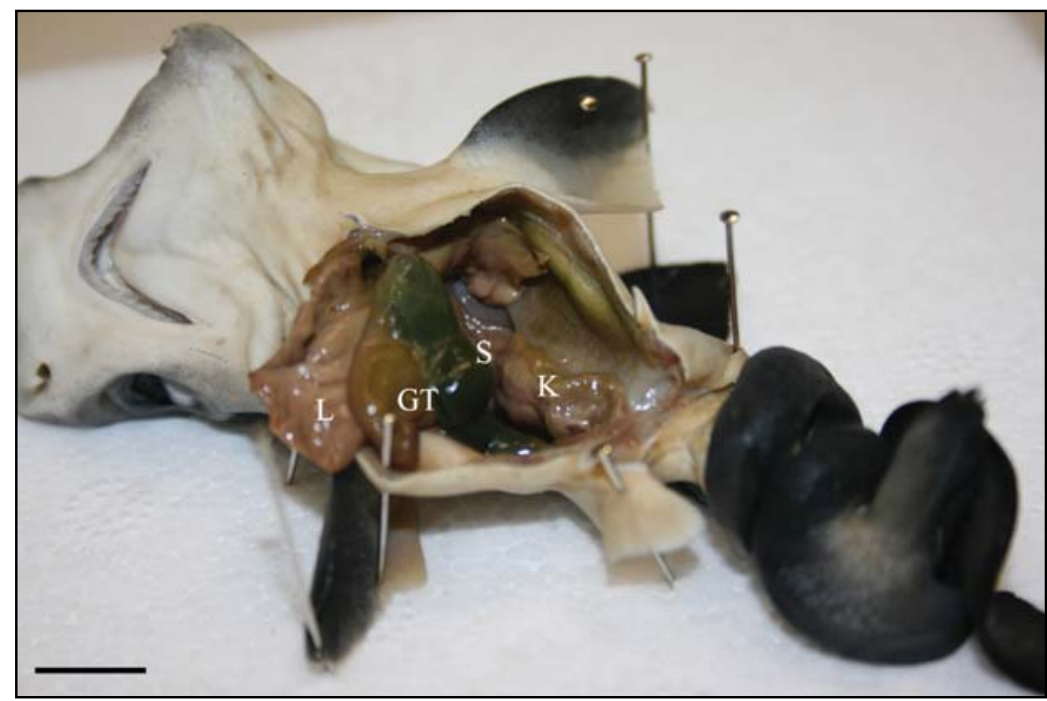

Figure 3. Embryo's internal morphology (L-liver; GT-gastrointestinal tract; S-spleen; K-kidney). Scale bar $2 \mathrm{~cm}$.

spine presented increased radiopacity and superficial mineralization. The spine also showed a frontal and pronounced thoracic curvature just above the pectoral fins. Still, the spinal axis in the caudal peduncle was spiralized to the left totaling four laps. The radiography also allowed the visualization of two distinct skulls, both with soft tissue radiopacity and cranial origin to the hiomandibular apparatus. In the skull, no ocular orbits or jaw sharing were observed (Figure 4).

\section{DISCUSSION}

Here we present the first report of bicephaly for the species. Although there are R. lalandii specimens with the same anomaly at the UNESP Elasmobranch Collection and probably other collections, this is the first report published. In summary, the embryo has two heads with separated cranial boxes, being connected laterally in the lower cephalic region and fused to different degrees discarding diprosopus and

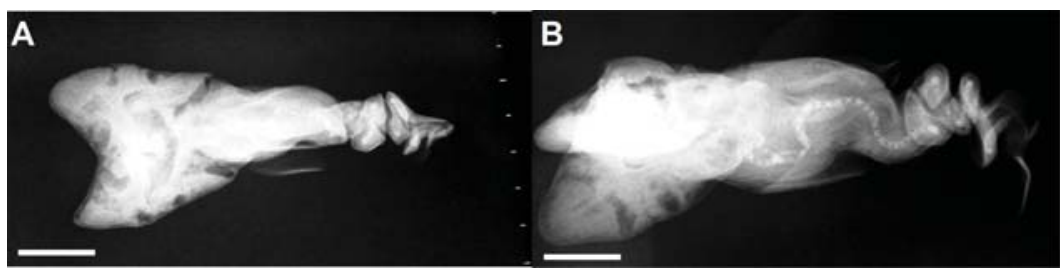

Figure 4. Embryo's radiography, highlighting the advanced lordosis and complete caudal torsion. Scale bar $1 \mathrm{~cm}$. 
confirming bicephaly, according Okazaki et al. (1987) and Kaufman (2004). Same patterns were already described for several vertebrates, indicating that such anomalies might be more common that the reported in the literature (Spencer, 2000). The probable cause of bicephaly is the incomplete division of the embryonic axis (Kaufman, 2004). However, other factors such as genetics, viral infections, metabolic disturbances, environmental changes, chemical contamination, maternal malnutrition and a high number of pups per gestation may be associated with developmental abnormalities (Kaufman, 2004; Biasibetti et al. 2011).

Considering external morphology, the right head (in dorsal view) was bigger with more developed teeth and rostrum compared to the left one. According to (Spencer, 2000) such pattern is common in bicephaly, being the more developed head the "real" embryo, and the other head the "parasitic twin". Bicephaly cases are relatively common in sharks (Lamarca et al. 2017; Sans-Coma et al. 2016) and more rarely seen in batoids. Due to the severity of the deformity, all cases already reported for sharks are in embryos, as survival is severely compromised due to reduced predatory efficiency. Even with all external deformities, the embryo showed normal, life-compatible internal morphology, indicating that whatever caused the malformation, only rigid structures were affected.

Although the size of the embryo is inconsistent with the birth size described for the species $(\sim 35 \mathrm{~cm}$ in LT) (Motta et al. 2007), its robust morphological characteristics such as the presence of developed teeth, dermal denticles, and skin pigmentation, similar to the characteristics of YOY and present in the literature for gender (Castro \& Wourms, 1993) indicate that this embryo was at an advanced stage of development. Its small size is probably linked to the severe caudal rotation observed, and the birth size may have been reached but was not visible. Most probably the anomaly occurred at the beginning of the embryonic development, since it usually occurs at the stage of neural tube duplication (Carles et al. 1995; Kaufman, 2004; DeLahunta \& Glass, 2009). Spine deformities are among the most commonly observed in sharks (Dos Santos \& Gadig, 2014; Lamarca et al. 2017). In fact, spinal anomalies occur at different levels, from mild lordosis to lifeincompatible spinal rotation due to the likely inability to swim normally (Pastore \& Prato, 1989; Mancini et al. 2006; Muñoz-Osorio et al. 2013; Dos Santos \& Gadig, 2014). The embryo of the present study showed not only advanced lordosis but also kyphosis and extreme posterior rotation, indicating that its survival outside the maternal uterus would be severely compromised. Still, according to the literature, the mineralization observed in the embryo spine is relatively common for some shark species (Stoskopf, 1993).

In summary, the present study reports the first published case of bicephaly in Rhizoprionodon lalandii, as well as other associated abnormalities. These reports are important as they help to determine the frequency and types of anomalies in elasmobranchs, providing not only greater insight into the congenital abnormalities in the group and their possible causes, but also helping map out in which species abnormalities are most common and in which regions they most often occur. Further studies should consider not only embryo analysis, but also maternal evaluation whenever possible. Still, efforts should be made in order to advance the understanding of the possible causes, through complementary toxicological, genetics and physiological analyzes.

\section{ACKNOWLEDGEMENTS}

The authors would like to thank the artisanal fishermen of Matinhos municipality for all research support, especially to Paulo, for providing us with the animal. The Hospital Veterinário do Batel and collaborating veterinarians for the x-ray images. The authors also thank the MarBrasil Association and Petrobras Socioambiental for logistical support through the Marine Biodiversity Recovery Program (REBIMAR).

\section{REFERENCES}

BERZINS, I. K., WALSH, M. \& RICHARDS, M. 2002. Spinal deformities in captive sandtiger sharks (Carcharias taurus). In Proc. 27th Ann. Eastern Fish Health Workshop: 18-20.

BIASIBETTI, E., D’ANGELO, A., BELLINO, C., GAY, L., GIANELLA, P., \& CAPUCCHIO, M. T. 2011. Diprosopia/Dicephalia in Calves in Northern Italy: Clinical and Aetio - Pathological Features. Anatomia, histologia, embryologia, 40(6), 433-440.

BONDENSON, J. 2001. Dicephalous conjoined twins: a historical review with emphasis on viability. J. Pediatr. Surg., 36: 1435-1444.

BORNATOWSKI, H. \& ABILHOA, V. 2009. Record of an anomalous embryo of Rhinobatos percellens (Elasmobranchii: Rhinobatidae) in the southern coast of Brazil. Mar. Biodivers. Rec., 2.

BORNATOWSKI, H. \& ABILHOA, V. 2012. Tubarões e raias capturados pela pesca artesanal no Paraná: guia de identificação. Hori Consultoria Ambiental, Curitiba.

CARLES, D., WEICHHOLD, W., ALBERTI, E. M., LEGER, F., PIGEAU, F. \& HOROVITZ, J. 1995. Diprosopia revisited in light of the recognized role of neural crest cells in facial development. J. Cran. Genet. Dev Biol., 15(2): 90-97.

CASTRO-AGUIRRE, J. L. \& TORRES-VILLEGAS, J. R. 1979. Sobre un caso de bicefalia funcional en Rhinoptera steindachneri Evermann Y Jenkins (Chondricthys, Elasmobranchii, Batoidei), capturado en 
la costa occidental de Baja California, Mexico. Cienc. Mar., 6(1): 27-41.

CASTRO, J. I., \& WOURMS, J. P. 1993. Reproduction, placentation, and embryonic development of the Atlantic sharpnose shark, Rhizoprionodon terraenovae. Journal of Morphology, 218(3), 257-280.

COMPAGNO, L. J. V. 1984. Sharks of the world. An annotated and illustrated catalogue of shark species known to date. Food and Agriculture Organization of the United Nations, Rome. Carcharhiniformes. FAO Fish Synopisys., 4: 251-655.

COMPAGNO, L.; DANDO, M. \& FOWLER, S. 2005. Sharks of the World. Princeton, NJ: Princeton University Press.

COSTA, L. \& CHAVES, P. D. T. D. C. 2006. Elasmobrânquios capturados pela pesca artesanal na costa sul do Paraná e norte de Santa Catarina, Brasil. Biota Neotrop., 6(3).

DELAHUNTA, A. \& GLASS, E. 2009. Veterinary neuroanatomy and clinical neurology. Saunders Elsevier.

DELPIANI, S. M., DELI ANTONI, M. Y., BARBINI, S. A. \& FIGUEROA, D. E. 2011. First record of a dicephalic specimen of tope Galeorhinus galeus (Elasmobranchii: Triakidae). J. Fish Biol., 78(3): 941944.

DOS SANTOS, C. M. H. \& GADIG, O. B. F. 2014. Abnormal embryos of sharpnose sharks, Rhizoprionodon porosus and Rhizoprionodon lalandii (Elasmobranchii: Carcharhinidae), from Brazilian coast, western South Atlantic. Mar. Biodivers. Rec., 7.

FIGUEIREDO, J.L. 1977 Manual de peixes marinhos do sudeste do Brasil. São Paulo: Museu de Zoologia, Universidade de São Paulo.

GADIG, O. B. F., F. S. Motta \& R. C. NAMORA. 2002. Projeto Cação - a study on small coastal sharks in São Paulo, southeast Brazil. Sustainable Management of Coastal Ecosystems Portugal. 239-246 p.

GALVÁN-MAGAÑA, F., ESCOBAR-SÁNCHEZ, O. \& CARRERA-FERNÁNDEZ, M. 2011. Embryonic bicephaly in the blue shark, Prionace glauca, from the Mexican Pacific Ocean. Mar. Biodivers. Rec., 4.

KAUFMAN, M.H. 2004. The embryology of conjoined twins. Child's Nervous System 20. 508-525 p.

LAMARCA, F., RIBEIRO, N., GALHEIGO, F., \& VIANNA, M. 2017. The first recordo of diprosopus tetrophthalmus in the South Atlantic Ocean: The case of Prionace glauca (Elasmobranchii: Carcharhinifor mes:Carcharhinidae) in Brazil. Acta Ichthyologica et Piscatoria, 47(4).
MANCINI, P. L., CASAS, A. L. \& AMORIM, A. F. 2006. Morphological abnormalities in a blue shark Prionace glauca (Chondrichthyes: Carcharhinidae) foetus from southern Brazil. J. Fish Biol., 69(6): 18811884.

MOTTA, F. S., GADIG, O. B., NAMORA, R. C. \& BRAGA, F. M. 2005. Size and sex compositions, length-weight relationship, and occurrence of the Brazilian sharpnose shark, Rhizoprionodon lalandii, caught by artisanal fishery from southeastern Brazil. Fish. Res., 74(1-3): 116-126.

MOTTA, F. S., NAMORA, R. C., GADIG, O. B., \& BRAGA, F. M. S. 2007. Reproductive biology of the Brazilian sharpnose shark (Rhizoprionodon lalandii) from southeastern Brazil. ICES Journal of Marine Science, 64(9), 1829-1835.

MUÑOZ-OSORIO, L. A., MEJÍA-FALLA, P. A. \& NAVIA, A. F. 2013. First record of a bicephalic embryo of smalltail shark Carcharhinus porosus. J. Fish Biol., 82(5): 1753-1757.

OKAZAKI, J.R., WILSON, J.L., HOLMES, S.M. \& VANDEMARK, L.L. 1987. Diprosopus: diagnosis in utero. Am. J. Roentgenol., 149 (1): 147-148.

SANS-COMA, V., RODRÍGUEZ, C., LÓPEZ-UNZU, M. A., LORENZALE, M., FERNÁNDEZ, B., VIDA, L., \& DURÁN, A. C. 2017. Dicephalous v. diprosopus sharks: record of a two-headed embryo of Galeus atlanticus and review of the literature. Journal of fish biology, 90(1), 283-293.

SPENCER, R. 2000. Theoretical and analytical embryology of conjoined twins: Part I: embryogenesis. Clin. Anat., 13: 36-53.

STOSKOPF, M. K. (1993). Fish medicine (Nº. V609 STOf).

PASTORE, M. \& PRATO, E. 1989. A teratologic case in a shark. Thalassia Salentina, 19: 87-92.

PÉREZ, A. E., BORGES, S. M., OLIVARES, F. R. \& RAREDON, S. J. 2018. First Case of Morphological Abnormality in Common Angel Sharks Squatina squatina. (Chondrichthyes: Squatinidae), from the Canary Islands. Tur. J. Fish. Aqua. Sci., 19(3): 267-270.

PREZIOSI, R., GRIDELLI, S., BORGHETTI, P., DIANA, A., PARMEGGIANI, A., FIORAVANTI, M. L. \& BERZINS, I. 2006. Spinal deformity in a sandtiger shark, Carcharias taurus Rafinesque: a clinical-pathological study. J. Fish. Dis., 29(1): 49-60.

WAGNER, C. M., RICE, P. H. \& PEASE, A. P. 2013. First record of dicephalia in a bull shark Carcharhinus leucas (Chondrichthyes: Carcharhinidae) foetus from the Gulf of Mexico, USA. J. Fish Biol., 82(4): 14191422. 